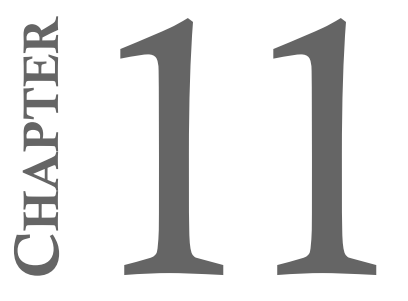

\title{
THE ICRMW AND THE US: SUBSTANTIVE OVERLAP, POLITICAL GAP
}

Beth Lyon *

\section{Introduction}

The United States has never seriously considered signing the UN International Convention on the Protection of the Rights of All Migrant Workers and Members of Their Families (ICRMW, Migrant Workers Convention, the Convention). ${ }^{1}$ Despite the country's close involvement with negotiating the Convention, the United States has shown no interest in the treaty since promulgation. By side-stepping a human rights approach, the US misses a chance to coherently administer low wage labour migration.

In the United States, all sides agree that irregular immigration is undesirable, yet the country is deeply divided on the solution. The groups wishing to discourage immigration typically advocate for tighter visa quotas, stricter border controls and more aggressive deportation measures. ${ }^{2}$ On the other hand, most migrants' rights advocates seek

* $\quad$ Clinical Professor of Law, Cornell Law School. This chapter contains passages from an earlier piece entitled 'The unsigned United Nations Migrant Worker Rights Convention: An overlooked opportunity to change the "brown collar" migration paradigm' (2010) 42 New York University Journal of International Law and Policy 389. The New York University Journal of International Law and Policy gave permission for this use of the 2010 article. Any errors are my own, but I am grateful to Alan Desmond, Nicola Piper, two anonymous reviewers, and research assistants Daniel Finnegan and Giulia Barbone for their invaluable comments and support. I also thank Cornell Law School for its financial support in the process of drafting this chapter.

1 International Convention on the Protection of the Rights of All Migrant Workers and Members of Their Families, GA (18 December 1990), UN Doc A/RES/45/158 (1990).

2 See Republican Platform 2016 (18 July 2016) https://prod-cdn static.gop.com/media/ documents/DRAFT_12_FINAL[1]-ben_1468872234.pdf 25-26, 42 (accessed 10 January 2017) (opposing amnesty and endorsing, inter alia, building a southern border wall, expedited removal for 'criminal aliens', and mandatory minimum five year sentence for re-entry); Federation for American Immigration Reform 'Immigration priorities for the 2017 presidential transition: A special report from the Federation for American Immigration Reform' http://www.fairus.org/DocServer/research-pub/ FAIR_2017PresidentialTransitionDocument.pdf (accessed 10 January 2017). 
legalisation and better workplace protections for all low wage workers, including those who are unauthorised migrants. ${ }^{3}$ Moderates of both wings favour temporary worker programmes as a way to control migration, though they differ over the optimal size and entry and work conditions of the temporary workforce. Compromise has proved near impossible through years of policy debate. The result is a series of superficial policy shifts that fail to address the underlying issues, producing an immigration regime that seems to be rudderless, offering only unenforceable and increasingly harsh laws.

In 1990, after ten years of negotiation that involved all regions of the world, ${ }^{4}$ the UN General Assembly adopted the ICRMW. To the surprise of the negotiators, the Convention was not widely ratified. ${ }^{5}$ The major countries of migrant employment that initially participated in negotiating the Convention set it aside ${ }^{6}$ and it languished for thirteen years before accruing the 20 ratifications it needed to enter into force. ${ }^{7}$ The treaty now has 38 signatories and 51 state parties. ${ }^{8}$

None of the current parties to the treaty is considered to be a country of major migrant employment, although some (Argentina, Belize, Libya and Venezuela) have significantly greater numbers of migrants per capita than other countries in their respective regions. ${ }^{9}$ Only three of the parties

3 Democrats 'Immigration Reform' https://www.democrats.org/issues/immigrationreform (accessed 10 January 2017) (pledging to work for 'comprehensive immigration reform' that 'keeps families together'); American Immigration Lawyers Association 'Featured issue: Earned legalization' (2 April 2014) http://www.aila.org/advo-media/ issues/immigration-reform/earned-legalization (accessed 10 January 2017); American Immigration Lawyers Association 'AILA: The time is now to move away from the negative rhetoric and commit to real immigration reform' (9 November 2016) http:// www.aila.org/advo-media/press-releases/2016/aila-move-away-from-the-negativerhetoric (accessed 11 January 2017); National Immigration Law Center 'The POWER Act: Protect our workers from Exploitation and Retaliation Act' (October 2015) https://www.nilc.org/wp-content/uploads/2015/12/power-act-2015-10-26.pdf (accessed 10 January 2017).

4 See LS Bosniak 'Human rights, state sovereignty and the protection of undocumented migrants under the International Migrant Workers' Convention' in B Bogusz et al (eds) Irregular migration and human rights: Theoretical, European and international perspectives (2004) 311, 312 \& n 6

5 See, generally, A Pécoud \& P de Guchteneire 'Migration, human rights and the United Nations: An investigation into the obstacles to the UN Convention on Migrant Workers' Rights' (2006) 24 Windsor Yearbook of Access to Justice 241244.

6 See Pécoud \& Guchteneire (n 5 above) 242

7 See United Nations Treaty Collection 'Status of International Convention on the Protection of the Rights of All Migrant Workers and Members of Their Families' https://treaties.un.org/Pages/ViewDetails.aspx?src=IND\&mtdsg_no=IV-13\&chapter $=4 \&$ clang=_en (accessed 5 February 2017) (ICRMW Ratification Record); see also ICRMW, art 87(1).

8 ICRMW Ratification Record (n 7 above).

9 See UN Department of Economic and Social Affairs 'International migration 2015' http://www.un.org/en/development/desa/population/migration/publications/wall chart/docs/MigrationWallChart2015.pdf (accessed 10 January 2017) (showing Argentina and Venezuela host $4,8 \%$ and $4,5 \%$ respectively, as compared with a South American regional average of $1,4 \%$, Belize has $15 \%$ per capita as compared with the regional Central American average of 1,2\%, and Libya has 12,3\% compared with the regional Northern Africa average of $1 \%$ ) 
to the treaty are high-income countries: Chile, Seychelles, and Uruguay. ${ }^{10}$ The three lowest-income OECD countries, Chile, Mexico, and Turkey, are parties to the Convention. ${ }^{11}$ There is some movement toward ratification in the industrialised world. The European Parliament, ${ }^{12}$ the European Economic and Social Committee, ${ }^{13}$ and the Organisation of American States ${ }^{14}$ have all favourably reported on the ICRMW and called on the countries in those regions to ratify it. However, there are obstacles to immediate ratification by countries of employment, including prominently the "fear to be among the first" ${ }^{15}$ and domestic anti-immigrant sentiment. ${ }^{16}$ Even as the Convention slowly accrues country-of-origin ratifications, advocates and officials in many countries of employment are undertaking pre-ratification studies of the treaty vis-à-vis domestic law and the difficult politics of immigration.

Meanwhile, the US has not yet assessed the Migrant Workers Convention in a substantive way. The United States' delay in engaging the Convention fits the country's past human rights treaty ratification processes. When it does consider the ICRMW, the US is likely to heavily restrict ratification of the Convention, just as it has in ratifying previous human rights treaties. This chapter describes the United States' substantive objections during the treaty negotiations, and points out that most of the passages that were objectionable at the time were or have since become part of US law.

\section{Brushing the dust off the UN Migrant Workers Convention}

Many industrialised countries of employment, or destination countries, including the United States, participated actively in the Migrant Workers

10 See The World Bank 'High income' http://data.worldbank.org/income-level/highincome?view=chart (accessed 8 January 2017).

11 See OECD 'List of OECD Member Countries - Ratification of the Convention on the OECD' http://www.oecd.org/about/membersandpartners/list-oecd-member-coun tries.htm (accessed 12 January 2017); Index Mundi 'Country Comparison - GDP Per Capita (PPP)' http://www.indexmundi.com/g/r.aspx?v=67 (accessed 12 January 2017).

12 See Resolution on the EU's Rights, Priorities and Recommendations for the 58th Session of the UN Commission on Human Rights in Geneva, CHR (31 January 2002), Eur Parl Doc P5-TA (2003)0034 5.

13 Opinion on the International Convention of Migrants, EESE (30 June 2004), SOC/ 173 (2004). For detailed discussion of the EU context, see the chapter by Desmond in this volume.

14 See The human rights of all migrant workers and their families, AG (4 June 2002), AG/RES 1898 (XXXII-O/02) (2002) (Resolution adopted at the fourth plenary session held on 4 June 2002).

15 See N Piper \& R Iredale 'Identification of the obstacles to the signing of the United Nations Convention on the Protection of the Rights of All Migrant Workers 1990: The Asia-Pacific perspective' (2004) Asia Pacific Migration Research Network (Working Paper 14) 8; Pécoud \& Guchteneire (n 5 above) 258.

16 See Pécoud \& Guchteneire (n 5 above) 259-61. 
Convention's ten-year drafting process. Twenty five years later, not one of these countries has signed or ratified the Convention. ${ }^{17}$ During those 25 years, the United States has ratified six other human rights treaties. ${ }^{18}$

\subsection{The Migrant Workers Convention has passed through few stages of the US multilateral treaty-making process}

Article II of the US Constitution sets forth the basic requirements of the US ratification process: '[The President] shall have Power, by and with the Advice and Consent of the Senate, to make Treaties, provided two thirds of the Senators present concur ... ${ }^{19}$ The framers' intent was for the Senate to be closely involved in all stages of the treaty-making process. ${ }^{20}$ However, the Senate's role in the treaty-making process changed as the body expanded and the number of international agreements became too great to make close involvement in negotiation practicable. ${ }^{21}$ According to a Congressional Research Service Handbook on the treaty-making process,

the Senate role [in treaty formation] now is primarily to pass judgment on whether completed treaties should be ratified by the United States. The Senate's advice and consent is asked on the question of Presidential ratification. ${ }^{22}$

The Handbook describes modern multilateral treaty-making ${ }^{23}$ as a ten-step process: ${ }^{24}$ (1) the Secretary of State authorises negotiation; (2) the US representative negotiates with representatives of other country or countries; (3) negotiators agree on terms and, upon authorisation of the Secretary of State, the US representative signs the treaty; (4) the President may submit the treaty to Senate; (5) the Senate Foreign Relations

17 See ICRMW Ratification Record (n 7 above); see also The Migrant Workers Convention, art 87(1). Note that the USSR, listed in $\mathrm{n} 25$ as a country-of-employmentparticipant in the negotiations, has since dissolved, but its major successor nation, Russia, has not ratified the ICRMW.

18 The United States has ratified the following six international human rights treaties since 1990: (1) in 1992 the International Covenant on Civil and Political Rights (ICCPR); (2) in 1994 the International Convention on the Elimination of all forms of Racial Discrimination (CERD); (3) in 1994 the Convention against Torture and Other Cruel, Inhuman or Degrading Treatment or Punishment (CAT); (4) in 1999 the Convention Concerning the Prohibition and Immediate Action for the Elimination of the Worst Forms of Child Labour; (5) in 2002 the Optional Protocol to the Convention on the Rights of the Child on the Involvement of Children in Armed Conflict; and (6) in 2002 the Optional Protocol to the Convention on the Rights of the Child on the Sale of Children, Child Prostitution and Child Pornography.

19 US Const art II, \& 2, cl. 2.

20 See Congressional Research Service 106th Congress Treaties and other international agreements: The role of the United States Senate: A study prepared for the Committee on Foreign Relations, United States Senate (2001) 2-3.

21 As above.

22 Congressional Research Service (n 20 above) 3.

23 Different processes apply to Executive Agreements and bilateral treaties. See Congressional Research Service (n 20 above) 21-26, 8-9, 10.

24 Congressional Research Service (n 20 above) 8-9. 
Committee considers the treaty and decides whether to report it favourably to the Senate; (6) the whole Senate may consider the treaty, and a 2/3 majority may vote to approve a resolution of ratification, and the Senate may 'approve it as written, approve it with conditions, reject and return it, or prevent its entry into force by withholding approval'; 5 (7) after renegotiating any terms brought into question by the ratification resolution, the President may sign the instrument of ratification; (8) the President may deposit the instrument of ratification with the designated depository, whereupon (9) the treaty enters into force according to its terms, and thereby becomes binding under international law; and (10) the President proclaims entry into force, providing domestic notification of the new law.

\subsubsection{Steps one and two: Active executive engagement in negotiation}

Professor Louis Henkin invoked the flying buttress as a metaphor of the United States' relationship to the international human rights treaty regime - in the words of Professor Margaret McGuinness, 'the US supports the cathedral of international human rights from the outside, rather than as a pillar from within the system'. ${ }^{26}$ One reason for this image is that the United States historically participates actively in human rights treaty development but does not readily join human rights treaties as a party subject to international monitoring.

Through Eleanor Roosevelt, the United States was instrumental in steering the Universal Declaration of Human Rights (Universal Declaration $)^{27}$ to successful completion. ${ }^{28}$ Subsequently the United States continued to play an active role in negotiating major human rights treaties. $^{29}$ In fact, past US executives carried out negotiations on human rights treaties over the objections of the Senate and established domestic actors. For example, the United States was heavily involved in negotiating the ICCPR despite domestic outrage over the socialist nature of the rights it contained. ${ }^{30}$ US participation in negotiations leading to the International Criminal Court similarly suffered from the opposition of the Department of Defence. ${ }^{31}$ Negotiation of the Migrant Workers

25 n 20 above, 3.

26 ME McGuinness 'Sanchez-Llamas, American human rights exceptionalism and the VCCR norm portal' (2007) 11 Lewis \& Clark Law Review 4752 (citing L Henkin 'Rights: American and human' (1979) Columbia Law Review 405 421).

27 Universal Declaration of Human Rights, GA Res 217A (12 December 1948), UN Doc A/810 (1948).

28 See NH Kaufman Human rights treaties and the Senate: A history of opposition (1990) 6667.

29 See, eg, LA Rehof Guide to the Travaux Préparatoires of the United Nations Convention on the Elimination of all Forms of Discrimination against Women (1993); S Detrick (ed) The United Nations Convention on the Rights of the Child: A guide to the 'Travaux Préparatoires' (1992).

30 See Kaufman (n 28 above) 69-93.

31 J Stork 'International Criminal Court' (1998) 4 Foreign Policy in Focus 1 1-3. 
Convention appears to have had a less controversial domestic backdrop, however, and the United States engaged in the process.

In 1979, the UN General Assembly created a Working Group to draft a convention to protect migrant workers and their families. ${ }^{32}$ Although the United States abstained from this vote, ${ }^{33}$ the formal reports of the Working Group reflect hundreds of interventions by the United States over the ten years of negotiations. ${ }^{34}$ On more than one occasion, the United States was instrumental in breaking impasses by proposing compromise language, participating in informal consultations, 35 and registering its underlying understanding of particular provisions. ${ }^{36}$

During the negotiations, the United States occasionally expressed ambivalence about the Convention. In 1986, the US Working Group representative stated that a reservation to Convention article 16(9) would likely be registered 'if and when the present Convention is submitted to the Senate'. ${ }^{37}$ In 1987, the US Representative

stated that his Government was not yet convinced of the need for a convention on the human rights of migrant workers, and that if such a need were demonstrated, such a convention should be negotiated in [the] ILO. ${ }^{38}$

At the same time, the negotiation history reveals a United States that was committed to the goals of the Convention. For example, the United States

32 Measures to Improve the Situation and Ensure the Human Rights and Dignity of All Migrant Workers, GA (17 December 1979), UN Doc A/RES/34/172 (1979) 3.

33 United Nations Bibliographic Information System 'Voting Record for A/RES/34/ 172' http://unbisnet.un.org:8080/ipac20/ipac.jsp?session=147W47X4410Q2.12957 $3 \&$ menu $=$ search \&aspect $=$ power $\&$ npp $=50 \& i p p=20 \& s p p=20 \&$ profile $=$ voting \&ri $=\&$ in $\mathrm{dex}=. \mathrm{VM} \&$ term $=$ res $+34 \% 2 \mathrm{~F} 172 \&$ matchoptbox $=0 \% 7 \mathrm{C} 0 \&$ oper $=\mathrm{AND} \& \mathrm{x}=0 \& \mathrm{y}=0 \&$ as pect $=$ power\&index $=$. VW\&term $=\&$ matchoptbox $=0 \% 7 C 0 \&$ oper $=A N D \&$ index $=. A D$ \&term $=\&$ matchoptbox $=0 \% 7$ C0\&oper $=$ AND\&index $=$ BIB\&term $=\&$ matchoptbox $=0$ $\% 7 C 0 \& u l$ type $=\&$ uloper $=\% 3$ D \&ullimit $=\& u l t y p e=\& u l o p e r=\% 3 D \& u l l i m i t=\&$ sort (accessed 20 December 2009).

34 See, eg, Measures to Improve the Situation and Ensure the Human Rights and Dignity of all Migrant Workers: Report of the Open-Ended Working Group, ECOSOC (25 November 1980), UN Doc A/C.3/35/13 (1980) annex VI; Measures to Improve the Situation and Ensure the Human Rights and Dignity of all Migrant Workers Report of the Open-Ended Working Group, ECOSOC (23 November 1981), UN Doc A/C/36/10 (1981) 31; Working Group on the Drafting of an International Convention on the Protection of the Rights of All Migrant Workers and Their Families, Report of the Open-Ended Working Group on the Drafting of an International Convention on the Protection of the Rights of All Migrant Workers and Their Families, ECOSOC (10 October 1986), UN Doc A/C.3/41/3 (1986) hereinafter (October 1986 Working Group Report).

35 See, eg, Measures to Improve the Situation and Ensure the Human Rights and Dignity of all Migrant Workers: Report of the Open-Ended Working Group, ECOSOC (23 November 1981), UN Doc A/C.3/36/10 (1981) 31

36 See, eg, Report of the Open-Ended Working Group on the Drafting of an International Convention on the Protection of the Rights of All Migrant Workers and Their Families, ECOSOC (21 June 1990), UN Doc A/C.3/45/1 (1990) 34.

37 October 1986 Working Group Report (n 34 above) 226.

38 Report of the Open-Ended Working Group on the Drafting of an International Convention on the Protection of the Rights of All Migrant Workers and Their Families, ECOSOC (22 June 1987), UN Doc A/C.3/42/1 (1987) 326. 
introduced and successfully advocated for Convention coverage of foreign investors, thereby creating a new category of protection under the treaty. ${ }^{39}$ The United States also sought successfully to broaden the Convention's protection of migrants' associational rights. ${ }^{40}$ In the June 1989 Working Group session, the first in which the Bush administration participated, the US Representative made a statement that was taken to be a change of position by the United States. The Representative urged that the Working Group take the time to iron out the final details of the Convention before submitting it to the General Assembly. ${ }^{41}$ In his remarks, the US Representative stated that ' $[\mathrm{m}] \mathrm{y}$ delegation is pleased that the Working Group has made substantial progress this session towards completing the Convention'. ${ }^{42}$ The representatives of several other countries immediately associated themselves with this intervention. ${ }^{43}$ According to the reported reaction of the Moroccan Representative,

the statement by the United States was very useful, especially since in the Third Committee the United States delegation had always voted against the resolution of the draft Convention that the Working Group was in the process of drafting. ${ }^{44}$

Working Group Vice-Chairman Juhani Lönnroth observed that, during the negotiations between 1979 and 1989:

There was a rather widespread belief that the United States would not sign and ratify the Convention in the immediate future. But it was equally evident that the United States wished to make the draft meet high legal standards and to make its content as close to its interests as possible in order to create prerequisites for an eventual ratification at some later stage. ${ }^{45}$

It is not clear whether the US delegation's positive contributions over the course of the treaty-drafting process reflected a change of heart by the Reagan administration, or merely due diligence to conduct the negotiations in a meaningful way.

39 See Report of the Open-Ended Working Group on the Drafting of an International Convention on the Protection of the Rights of All Migrant Workers and Their Families, ECOSOC (15 October 1985), UN Doc A/C.3/40/6 (1985) 104-111.

40 See ECOSOC Report (n 38 above) 236.

41 See Report of the Open-Ended Working Group on the Drafting of an International Convention on the Protection of the Rights of All Migrant Workers and Their Families, ECOSOC (19 June 1989), UN Doc A/C.3/44/1 (1989) 307.

42 n 41 above, 307.

43 n 41 above, 308-09.

$44 \mathrm{n} 41$ above, 311.

45 J Lönnroth 'The International Convention on the Rights of All Migrant Workers and Members of Their Families in the context of international migration policies: An analysis of ten years of negotiation' (1991) 25 International Migration Review 710734. 


\subsubsection{Steps three and four: Delayed executive signature and submission to Senate, and the slow move from the 'flying buttress' to the 'pillar from within'}

The United States' delay between promulgation and signature of the Migrant Workers Convention is not unusual. Step three in the generic treaty process laid out above, 'negotiators agree on terms and, upon authorization of the Secretary of State, the US representative signs the treaty,' appears to anticipate that an executive, fresh from negotiating the terms of a treaty and voting for its promulgation, will sign the document. ${ }^{46}$ However, in the case of human rights treaties, the more common occurrence is a significant delay between promulgation and US signature. Thus the vast majority of human rights treaties are shepherded through the ratification process by an executive that did not negotiate them.

According to a Department of State Treaty Analyst writing in 2008, the executive branch has given 'no serious consideration' to signing either the ICRMW, or the ILO Conventions that deal with migrant workers. ${ }^{47}$ Interviews with domestic and international government officials and advocates reveal that the Migrant Workers Convention receives virtually no attention in the United States from either civil society or government because of the assumption that any attempt to define immigrants as rights holders is a political non-starter. ${ }^{48}$

In the case of the Convention on the Elimination of Discrimination against Women, in 198020 members of the House of Representatives introduced a resolution urging the President to sign the treaty. ${ }^{49}$ Meanwhile, the Migrant Workers Convention has received virtually no public attention from the Senate. ${ }^{50}$ Even the UN Economic and Social Council, when it commissioned a series of studies on the Convention's prospects for ratification in a variety of countries, did not examine the United States. 51

\subsubsection{Delayed Senate approval}

From the earliest days of the human rights treaty regime, the Senate has struggled with whether and how to incorporate international norms into domestic law. ${ }^{52}$ Even when the content of a treaty appears to be

46 See n 20 and n 23 above and accompanying text.

47 E-mail from J Sherer on 24 January 2008.

48 E-mail from J Sherer (n 47 above); E-mail from A Pécoud on 1 October 2008.

49 See H Res 738 (96th) (1980): A resolution relating to the United Nations Mid-Decade Conference for Women.

50 In a search of the Congressional Record, I found only one mention of the Migrant Workers Convention, a reference in a written statement by the International Council of Voluntary Agencies entered by Senator Ted Kennedy in 1992138 Cong Rec S 106, 111 (22 January 1992).

51 See E-mail from A Pécoud (n 48 above). 
unobjectionable, for example in the case of the Genocide Convention, concerns about loss of sovereignty seem to hold particular sway in the realm of human rights treaty ratification. ${ }^{53}$ According to Professor Natalie Kaufman, 'the actual content of the treaties is not viewed as the primary determinant of the current situation. Perception is important, not content. ${ }^{54}$ Given the sensitive nature of immigration policy, it is likely that a convention on migrant workers' rights would also encounter opposition and lengthy debates.

\subsubsection{Restrictions on ratification}

It is common for the United States to aggressively seek to limit the consequences of human rights treaty ratification on the domestic legal system. ${ }^{55}$ Restrictions on ratification, in the form of reservations, understandings, and declarations (RUDs), serve this function. ${ }^{56}$ When the earliest human rights treaties were promulgated, the question of the appropriate way to handle these restrictions was unsettled. ${ }^{57}$ The international community had to strike a balance between universality, in the form of widespread ratification, and the integrity of the treaty. ${ }^{58}$ Therefore, state parties may make unilateral reservations to human rights treaties. This is permitted only when reservations do not contravene the 'object and purpose' of the treaty, ${ }^{59}$ a norm that has proven to be virtually ineffective as a barrier to unilateral reservations on ratification. ${ }^{60}$

In its ratification of human rights treaties, the United States has taken this practice further than with respect to any other type of treaty. ${ }^{61}$ In fact, it has regularly applied a set of restrictions based on what the late Senator Jesse Helms termed the 'sovereignty package' ${ }^{62}$ Over the years, the 'sovereignty package', as applied in the context of human rights treaties, has evolved to include the following restrictions: an 'understanding' that assures federal and state government cooperation to ensure compliance

52 See Kaufman (n 28 above) 2. The US Senate Subcommittee on Human Rights and the law held a hearing on this issue, which was long overdue. For the archived webcast, see US Senate Committee on the Judiciary 'The law of the land: US implementation of human rights treaties' http://judiciary.senate.gov/hearings/hearing.cfm?id=4224 (accessed 16 December 2009).

53 Written statement by the International Council of Voluntary Agencies (n 50 above) 287-88; see also Kaufman (n 28 above) 184-193.

54 Kaufman (n 28 above) 181.

55 See E Neumayer 'Qualified ratification: Explaining reservations to international human rights treaties' (2007) 36 Journal of Legal Studies 397404 (calling the United States a 'notorious example' of the use of RUDs).

56 As above.

57 See L Lijnzaad Reservations to un-human rights treaties: Ratify and ruin? (1995) 15.

58 See Lijnzaad (n 57 above) 23.

59 Lijnzaad (n 57 above) 28-29.

60 Lijnzaad (n 57 above) 95.

61 Congressional Research Service (n 20 above) 286.

62 Kaufman (n 28 above) 187. 
with the treaty; ${ }^{63}$ a declaration that the terms of the treaty are not 'selfexecuting', or not enforceable in domestic court, until they have been implemented in domestic legislation; 64 and an understanding that 'nothing in [the treaty] establishes a basis for jurisdiction by any international tribunal, including the International Criminal Court' ${ }^{65}$ The 'sovereignty package' is controversial internationally. The US ratification restrictions have garnered formal protests from other state parties to human rights treaties, ${ }^{66}$ sparked inter-governmental policy statements designed to limit restrictions, ${ }^{67}$ and elicited widespread censure from domestic constituencies. ${ }^{68}$ While the question of whether non-self-execution can be read into a treaty that was not ratified on that explicit understanding has been the subject of debate and litigation, ${ }^{69}$ US courts do enforce explicit non-self-execution ratification restrictions. ${ }^{70}$

63 United Nations Treaty Collection 'Status of International Covenant on Civil and Political Rights' http://treaties.un.org/doc/Publication/MTDSG/Volume\%20I/ Chapter\% 20IV/IV-4.en.pdf (accessed 6 November 2016); United Nations Treaty Collection 'Status of International Convention on the Elimination of All Forms of Racial Discrimination' https://treaties.un.org/Pages/ViewDetails.aspx?src=IND\& mtdsg_no=IV-2\&chapter=4\&clang=_en (accessed 5 November 2016); United Nations Treaty Collection 'Status of Optional Protocol to the Convention on the Rights of the Child on the Involvement of Children in Armed Conflict' https://treaties.un.org/ Pages/ViewDetails.aspx?src=IND\&mtdsg_no=IV-11-b\&chapter=4\&clang=_en (accessed 6 November 2016).

64 As above.

65 Status of Optional Protocol to the Convention on the Rights of the Child on the Involvement of Children in Armed Conflict (n 63 above). Note also that two ratifications involved what Senator Helms termed the 'sovereignty proviso', conditions included in the Senate resolution ratifying the Genocide Convention but not included in the Convention against Torture instrument of ratification deposited by the President. Congressional Research Service (n 20 above) 134-35. The 'sovereignty proviso' stated that the President would not deposit the instrument of ratification until he had notified 'all present and prospective ratifying parties ... that nothing in this Convention requires or authorizes legislation, or other action, by the United States of America prohibited by the Constitution of the United States as interpreted by the United States.' Congressional Research Service (n 20 above) 134, 287.

66 See, eg, Status of International Covenant on Civil and Political Rights (n 63 above); United Nations Treaty Collection 'Status of Convention against Torture and Other Cruel, Inhuman or Degrading Treatment or Punishment' https://treaties.un.org/ pages/ViewDetails.aspx?src=TREATY\&mtdsg_no=IV-9\&chapter=4\&clang=_en (accessed 20 December 2009).

67 C Redgwell 'US reservations to human rights treaties: All for one and none for all?' in M Byers \& G Nolte (eds) United States hegemony and the foundations of international law (2003) 392, 397-98.

68 Eg, Press Release, American Civil Liberties Union and Human Rights Watch Report on US Violations of International Human Rights Covenant 'Groups call on Clinton administration to correct abuses, ensure that international standards can be invoked in US courts' (14 December 1993) http://www.skepticfiles.org/aclu/12_14_93.htm (accessed 5 November 2016).

69 The Supreme Court has read such a treaty to be non-self-executing and thus unenforceable in US courts. See Medellin v Texas 552 US 491, 505 (2008) (quoting Igartúa-De La Rosa v United States 417 F 3d 145, 150 (1st Cir 2005)). For scholarship on this issue, see MS Flaherty 'History right?: Historical scholarship, original understanding, and treaties as "supreme law of the land" (1999) 99 Columbia Law Review 2095; CM Vázquez 'Laughing at treaties' (1999) 99 Columbia Law Review 2154; CM Vázquez 'Treaties as law of the land: The supremacy clause and the judicial enforcement of treaties' (2008) 122 Harvard Law Review 600.

70 CA Bradley 'Our dualist Constitution, and the internationalist conception' (1999) 51 Stanford Law Review 529 539-40. 
In addition to the aforementioned understandings and declarations, the United States imposes additional restrictions it calls reservations, restricting its commitment to substantive provisions of human rights treaties that conflict - or potentially conflict - with domestic law. For example, in its ratification of the ICCPR, the United States reserved the right to execute convicted criminals for crimes committed below the age of $18^{71}$ to shield the United States from the ICCPR's prohibition on the juvenile death penalty. ${ }^{72}$ The US practice of participating in treaty negotiation while delaying and severely restricting ratification has earned it the label of a 'double standard state'. 73

\subsubsection{Domestic law assessment of the Migrant Workers Convention}

The provisions of the Convention that apply to undocumented migrants are, to a great extent, a recitation of international norms to which the United States has already acceded by virtue of previous treaty ratifications. ${ }^{74}$ In fact, 23 provisions of the ICRMW ${ }^{75}$ merely echo the language of treaties the US has ratified. ${ }^{76}$ An additional two provisions, which do not correspond to protections already ratified by the United States, adopt the language of the Universal Declaration, ${ }^{77}$ a document that the United States helped to draft ${ }^{78}$ and in favour of which the country voted in $1948 .{ }^{79}$ Moreover, each of these two provisions - protection from arbitrary deprivation of property and the right to secondary education for undocumented migrant children, is firmly established in US domestic

71 Status of International Covenant on Civil and Political Rights (n 63 above).

72 ICCPR, art 6(5). See generally Congressional Research Service (n 20 above) 291. For arguments against restrictions on ratification in general see L Henkin, 'The Covenant on Civil and Political Rights' in RB Lillick (ed) US ratification of the human rights treaties: With or without reservations? (1985) 22.

73 See Neumayer (n 55 above).

74 JAR Nafziger \& BC Bartel 'The Migrant Workers Convention: Its place in human rights law' (1991) 25 International Migration Review 771 781-82.

75 See Nafziger \& Bartel (n 74 above) 789-99; see also ICRMW, art 10 (corresponding to CAT art 16); art 16 (corresponding to CAT art 14).

76 See Nafziger \& Bartel (n 74 above) 789-99.

77 See ICRMW, art 15 (corresponding to Universal Declaration art 17); ICRMW, art 30 (corresponding to Universal Declaration art 26).

78 See MA Glendon $A$ world made new: Eleanor Roosevelt and the creation of the Universal Declaration on Human Rights (2000).

79 For information and background on the voting of states regarding the Universal Declaration, see generally Glendon (n 78 above) 143-72. Note that the Universal Declaration of Human Rights is a declaration, not a treaty, and therefore is not as a whole formally binding on the United States. See H Hannum 'The status of the Universal Declaration of Human Rights in national and international law' (1995-1996) 25 Georgia Journal of International and Comparative Law 287 290. Some provisions of the Declaration, such as the prohibition on torture contained in art 5, are now accepted by the US as binding on this country through the international law devices of customary international law. See Hannum 306; Filartiga v Pena-Irala 630 F 2d 876, 879 (2d Cir 1980). However, arts $17 \& 26$ of the Universal Declaration are not amongst these provisions. Nevertheless, the United States' endorsement of the Declaration lends weight to the argument that the above-mentioned parallel articles in the Migrant Workers Convention (arts 15 and 30) are not foreign to the United States. See generally Restatement (Third) of the Foreign Relations Law of the United States $§ 701$ (1987). 
law. ${ }^{80}$ Thus, a significant portion of the ICRMW overlaps with the United States' existing obligations.

The Senate and Administration are likely to be most protective of their immigration enforcement prerogatives. However, the Convention does not mandate legalisation. In fact, article 35 of the Convention clarifies that the treaty does not require governments to offer regularisation to undocumented migrants, though article 69 does set out factors to be taken into account when state parties consider the possibility of regularisation and article 22 places due process restrictions on individual expulsion decisions.

A sensitive area of immigration policy involves the visa eligibility of migrant workers' families. Article 38 requires states of employment to 'make every effort to authorize [legally present] migrant workers and [family members] to be temporarily absent without effect upon their authorization to stay or to work' ${ }^{81}$ With regard to workers who are lawful permanent residents (LPR), the United States makes precisely that provision, permitting LPR-status migrants to undertake temporary visits abroad without running any risk of jeopardising their status. ${ }^{82}$ With regard to temporary entrants, however, no such provision for temporary travel is made, potentially creating a de jure conflict between article 38 and US law.

Some Convention articles offer substantive immigration protections to legally present workers aimed at protecting family reunification. Article $44(2)$ directs that state parties

take measures that they deem appropriate and that fall within their competence to facilitate the reunification of [authorized] migrant workers with their spouses [or equivalents] ... as well as with their minor dependent unmarried children,

and directs that 'on humanitarian grounds, [state parties] shall favourably consider granting equal treatment to other family members of migrant workers'. ${ }^{83}$ As to the first requirement, the language 'take measures that they deem appropriate' prevents this clause from conflicting with domestic law. However, the second phrase requires examining whether those family reunification protections that are in place are being extended to 'other family members'. This, too, is a weak requirement, using the mandating language of 'shall favourably consider', but if that language were interpreted to be binding, the US domestic immigration system would present a de jure conflict with article 44 as well. There are numerous instances in US law of more favourable treatment for nuclear as opposed 
to extended, or 'other' family members. ${ }^{84}$ Similarly, if 'favourably consider' is interpreted to be binding, article 50(1) raises a de jure conflict. Article 50(1) requires states to 'favourably consider' granting family members of deceased or divorced migrant workers authorisation to stay and to take into account the length of time already spent in that state. ${ }^{85}$ These provisions, though arguably weakly worded, raise potential conflicts that would likely require either a change in US law to guarantee conformity or spark a restriction on ratification. ${ }^{86}$ Moving toward modifying US law on this point would better comport with the United States' obligation under ICCPR article 23(1) to treat the family as 'the natural and fundamental group unit of society[,] entitled to protection by society and the State'. 87

Thus US ratification of the ICRMW would likely be conditioned on a set of reservations, understandings and declarations, by way of an initial package proposed by the Executive upon signature, followed by Senate stipulation upon authorisation to ratify, and formalised by the final act of ratification by the President. These limitations would likely include the longstanding generic reservations, such as the federal/state understanding and the non-self-execution declaration, as well as a series of substantive reservations and declarations addressing both clear and potential substantive conflicts between the Convention and domestic law.

In future fuller assessments of the Convention, additional differences between US law and the Convention will be identified. In the context of such differences, however, it is important to underline that US ratification of human rights treaties typically includes a declaration that the treaty provisions are not 'self-executing'. This means that restrictions on ratification will likely prevent judicial reconciliation of de jure conflicts, because at first courts will not have jurisdiction over implementation of the treaty. The non-self-executing restriction on ratification would prevent any provision from being invoked in US domestic courts unless the legislature has 'executed' that provision in domestic legislation. This provision, along with the various substantive restrictions that are likely to limit ratification, appears to block domestic law from any real change in the absence of legislative implementation. ${ }^{88}$ Ratification of the Convention would involve the country in a much-needed self-examination process but would

84 Eg, TA Aleinikoff et al Immigration and citizenship: Process and policy (2003) 277-80.

85 ICRMW, art 50(1).

86 For example, the death of an immigration family petitioner, before the petition has been approved, as well as in most other situations, automatically revokes the petition and strips the family member of the petitioner of the right to status in the United States. See Abboud v INS 140 F 3d 843, 849 (9th Cir 1998); Dodig v INS 9 F 3d 1418 (9th Cir 1993).

87 ICCPR, art 23(1)

88 See Vázquez 'Treaties as law of the land' (n 69 above) 695; CM Vázquez 'Judicial enforcement of treaties: Self-execution and related doctrines' (2006) 100 American Society of International Law Proceedings 439 439. See generally RB Lillich (ed) US ratification of the human rights treaties: With or without reservations? (1981). 
not threaten longstanding policies. As noted above, this limited domestic role for ratified human rights treaties was not the original vision for the UN human rights treaty regime, but it is the likely short-term domestic legal effect of ratification of the Migrant Workers Convention in the US.

\subsection{US signature is unlikely, though the United States recently agreed to take 'deliberative action'}

For the first 21 years after promulgation of the Migrant Workers Convention, the US government rarely, if ever, publicly discussed it. Informal indications were that the Convention was extremely low on the list of ratification priorities. Despite President Obama's signature of the UN Convention on the Rights of Persons with Disabilities, ${ }^{89}$ his pledge to ratify several other international human rights treaties, ${ }^{90}$ his statements on the urgency of poverty alleviation in the Global South, ${ }^{91}$ and some steps to improving conditions for migrant workers, his administration's few statements on the ICRMW were uniformly negative.

The US had occasion to reaffirm its intentions with regard to the Convention when it passed through the UN's Universal Periodic Review (UPR) process in 2010-2011 and again in 2015. Participating states urged the United States to ratify a number of human rights treaties, and many included the Migrant Workers Convention in the list. ${ }^{92}$ Egypt, Turkey, and Guatemala made freestanding recommendations on the ICRMW alone, emphasising its importance over other unratified treaties. ${ }^{93}$ From the responses of the US representatives emerge three tiers of support for unratified human rights treaties. A handful of conventions received the strongest positive indications. These were the treaties the representatives

89 See The White House Office of the Press Secretary 'Remarks by the President on Signing of UN Convention on the Rights of Persons with Disabilities Proclamation' (24 July 2009) http://www.whitehouse.gov/the_press_office/Remarks-by-thePresident-on-Rights-of-Persons-with-Disabilities-Proclamation-Signing/ (accessed 5 November 2016).

90 'Obama pledge on treaties a complex undertaking' San Francisco Chronicle 1 December 2008 A1.

91 'Obama's $\$ 845$ billion UN plan forwarded to US Senate floor: "Global Poverty Act" to cost each citizen $\$ 2,500$ or more' WorldNetDaily 28 July 2008 http://www.wnd.com/ index.php?pageId=70308 (accessed 5 November 2016).

92 Report of the Working Group on the Universal Periodic Review*: United States of America, HRC (4 January 2011), UN Doc A/HRC/16/11 (2011) paras 92.1 (Bolivarian Republic of Venezuela), 92.6 (Sudan); 92.15 (Haiti) (2011 UPR USA Working Group Report); Report of the Working Group on the Universal Periodic Review* United States of America, HRC (20 July 2015), UN Doc A/HRC/30/12 (2015) paras 176.25 (Indonesia), 176.28 (Cabo Verde), 176.33 (Ghana), 176.53 (Honduras), 176.54 (Chile), 176.59 (Guatemala) (2015 UPR USA Working Group Report).

932011 UPR USA Working Group Report (n 92 above) paras 92.29 (Egypt), 92.30 (Turkey), 92.31 (Guatemala); 2015 UPR USA Working Group Report (n 92 above) para 176.59 (Guatemala) 
identified as those for which 'the Administration is most committed to pursuing ratification'. ${ }^{94}$ Without any qualifying language, the US expressed 'support' for the recommendations urging ratification of these instruments: the Convention on the Elimination of Discrimination against Women, the Convention on the Rights of Persons with Disabilities, and the ILO Convention concerning Discrimination in Respect of Employment and Occupation (ILO Convention No 111). ${ }^{95}$ At the second tier of support appears the Convention on the Rights of the Child (CRC). The US responded to the recommendations to ratify the CRC by indicating support expressed with the qualifier, 'as we support its goals and intend to review how we could move toward its ratification. ${ }^{96}$ At the lowest tier of support fall several treaties, ${ }^{97}$ including the Migrant Workers Convention. The US consistently responded to recommendations to ratify the ICRMW with 'we cannot support', 98 'we do not support', 99 or that the recommendation 'does not enjoy our support.' 100

There has, however, been one development that signaled a more nuanced US approach to the Migrant Workers Convention. In 2015, a few countries recommended that the US 'consider' ratifying particular treaties, including the ICRMW. ${ }^{101}$ The US responded: 'we support recommendations urging deliberative actions on treaties or domestic institutions, such as that we "consider" them'. ${ }^{102}$ At the UPR session wrapping up the 2015 US review, the representative of the Philippines welcomed the United States' acceptance of its recommendation to consider the ICRMW. ${ }^{103}$ It remains to be seen what a commitment to 'consider' and to take 'deliberative action' means for US review of the Convention. With the advent of a Trump administration, the promised deliberative action seems unlikely.

94 Report of the Working Group on the Universal Periodic Review United States of America Addendum Views on conclusions and/or recommendations, voluntary commitments and replies presented by the State under review*, HRC (8 March 2011), UN Doc A/HRC/16/11/Add.1 (2011) para 29 (hereinafter 2011 US UPR Response). 2011 US UPR Response (n 94 above) para 28.

962011 US UPR Response (n 94 above) para 28; Report of the Working Group on the Universal Periodic Review*: United States of America: Addendum: Views on conclusions and/or recommendations, voluntary commitments and replies presented by the State under review, HRC (14 September 2015), UN Doc A/HRC/30/12/Add.1 (2015) para 20 (hereinafter 2015 US UPR Response).

97 Other explicitly disfavoured treaties included the ICCPR, the International Convention for the Protection of All Persons from Enforced Disappearance (ICPED), the Optional Protocol to the ICCPR, the American Convention on Human Rights, the Rome Statute of the International Criminal Court, and the ILO Convention on Domestic Workers (No 189).

982011 US UPR Response (n 94 above) para 29.

992015 US UPR Response (n 96 above) para 22.

1002011 US UPR Response (n 94 above) para 30.

1012015 UPR USA Working Group Report (n 92 above) paras 176.55 (Burkina Faso), 176.60 (Philippines).

1022015 US UPR Response (n 96 above) para 28.

103 UN Web TV 'USA UPR adoption - 22nd Session of Universal Periodic Review' (15 May 2015) http://webtv.un.org/search/usa-upr-adoption-22nd-session-ofuniversal-periodic-review $/ 4238252840001$ ?term $=$ upr\&languages $=\&$ sort $=$ date (accessed 6 November 2016). 


\section{Lost opportunity to rationalise low wage labour migration policies}

By failing to sign or assess the Migrant Workers Convention, the United States misses an important opportunity to protect one of the country's most subordinated populations. By exposing more US citizens to the notion that migrant workers are the subjects of a human rights treaty, engaging with the Convention might contribute to shifting the political climate toward policy reform. Ratification would also improve the United States' reputation abroad, increasing its world leadership vis-à-vis the Global South, improving the US-Mexico relationship, and enabling the United States to shape the development of the emerging international law standards on migrant workers. Working with the Convention would also help the United States identify best practices and further badly needed cross-agency examination of this country's fragmented temporary worker programme.

In the words of Professor Oona Hathaway, 'treaties shape behavior not simply by influencing tangible benefits and not simply because they create legitimate legal obligations, but also by providing nations with a powerful expressive tool'. ${ }^{2}$ The United States desperately needs expressive tools for addressing migration. By restricting opportunities for legal low wage labour migration and failing to enforce employer sanctions, the United States has developed the world's largest per capita undocumented migrant population, one of the world's most deadly peacetime borders, and the most poverty-stricken low-income workforce in the industrialised world. Most agree, on humanitarian, labour, fiscal, international relations and security grounds, that these are urgent problems. Yet, except for policies of increased enforcement, domestic policy reform proposals have failed politically. Signature and ratification of the ICRMW would help to re-frame the debate on migrant labour and refocus attention on non-enforcement solutions to irregular migration, urging the United States along a path toward a rational global approach to low wage labour migration.

\section{Conclusion}

The United States has always had an unusually contradictory relationship with the Migrant Workers Convention. At the UN ECOSOC level, the United States routinely opposed promulgation of the treaty. However, once the Working Group tasked with drafting the Convention convened, the United States participated actively in negotiations, even on occasion

104 OA Hathaway 'Do human rights treaties make a difference?' (2002) 111 Yale Law Journal 19352020. 
lending its influence to breaking impasses and moving negotiations forward. Once negotiations concluded, however, the United States has given no serious consideration to signing the Convention. Most recently, while participating in the UPR, the US opposed calls for it to ratify the treaty, though it did respond favourably to one request to deliberate on the possibility of ratification. There is relatively little conflict between US law and the substantive protections of the Convention, and what conflicts may exist would likely be buffered upon ratification owing to the United States' typically aggressive practice of restrictions on ratification. Even with its general history of slow human rights treaty ratification, the United States' treatment of the ICRMW stands out as particularly delayed, owing not to concerns about law, but to the politicised nature of the country's low wage labour migration regulation. The politics of immigration continue to result in widespread suffering that could be lessened if the US legislature adopted a human rights framework in assessing its policy priorities. Engaging with the Migrant Workers Convention would be an important step toward recasting this fraught policy area. 